\section{Stanford psychiatrist removed from drug study}

Stanford University last week removed its chairman of psychiatry, Alan Schatzberg, as principal investigator from a National Institute of Mental Health (NIMH) grant, after a US Senate investigation raised questions about his impartiality in overseeing the grant.

The grant is for investigating the use of mifepristone, a steroid that is being developed for possible use in depression by Corcept Therapeutics, Menlo Park, California, which Schatzberg helped to found and in which he owns 2.7 million shares worth nearly US\$6 million.

"Despite our belief that Stanford, NIMH and Dr. Schatzberg have handled this in accordance with the regulations and applicable policies and with due regard to the integrity of the research, we can see how having Dr. Schatzberg as the principal investigator on this grant can create an appearance of conflict of interest and we want to eliminate that concern," Debra Zumwalt, Stanford's vice-president and general counsel, wrote in a 31 July letter to the NIMH.

\section{Third failure for private rocket launch}

The third attempt to launch the Falcon 1 rocket, built by privately funded company Space Exploration Technologies (SpaceX), has failed. The test flight took off on 2 August from Kwajalein atoll in the Pacific Ocean, but was scuppered minutes after launch when two rocket stages didn't separate.

Falcon 1 was carrying three payloads: a US Department of Defense satellite called Trailblazer, and two NASA satellites, NanoSail-D - which involves a solar sail and PRESat, a microlaboratory for testing biological samples in space.

SpaceX plans to continue testing Falcon 1 and is developing another rocket, Falcon 9, says chief executive Elon Musk.

Falcon 1's first test flight, in March 2006,

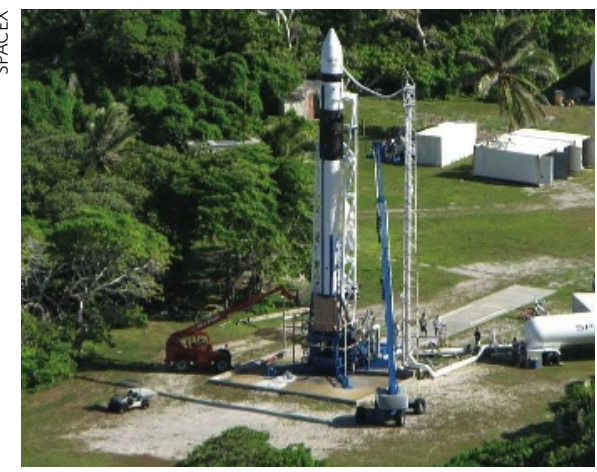

Falcon 1 prepares for its ill-fated launch.

\title{
Rock art carves itself a niche online
}

This series of concentric circles, carved on rocks in Northumberland, UK, is featured in a new catalogue (http:// archaeologydataservice. ac.uk/era) of carvings from the region. English Heritage, the government-funded body in charge of protecting historic sites, hopes that threedimensional models of the carvings uploaded to the Internet will help

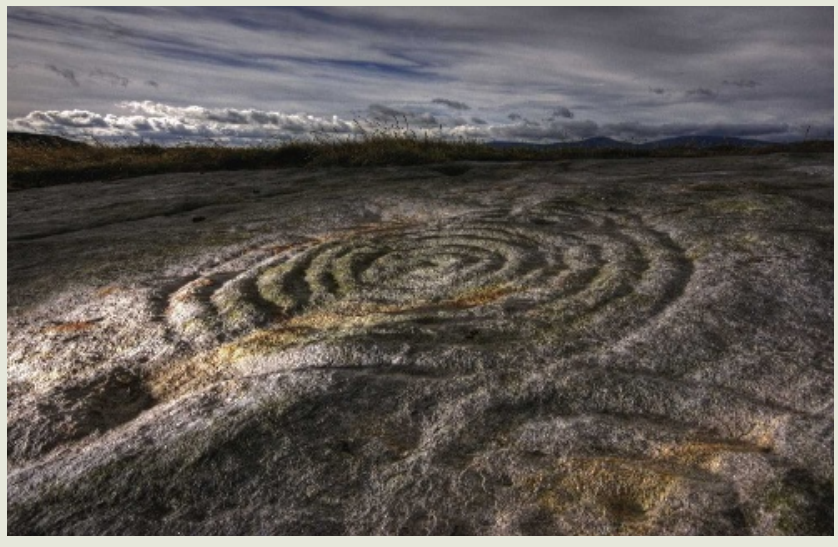
researchers and those working to preserve the art. The agency says around 2,500 rock carvings are currently known in England, and it expects to discover more with a national survey building on this regional work.

failed a minute after take-off because of a leaking fuel line. The second, a year later, launched but didn't make it to orbit.

\section{Canadian observatory sold to property developer}

The University of Toronto's David Dunlap Observatory has been sold to a development company.

Last week, Metrus Development announced its purchase of the 77-hectare park in Richmond Hill, which includes the observatory, an administrative building and an 1850s farmhouse, for Can $\$ 70$ million (US\$68 million). The university will share the proceeds with the Dunlap family, and plans to use its share for a new astronomy and astrophysics institute.

Metrus has pledged to maintain the three buildings, and has invited proposals from anyone interested in reopening and managing the observatory.

The university has run the 1.88-metre reflecting telescope, the largest in Canada, since 1935. But only two faculty members have used it in recent years, along with visiting scientists. "The department of astronomy has gone in a direction for which this observatory is no longer useful," says Robert Steiner, the university's assistant vice-president for strategic communications.

\section{Researcher wins claim for accidental infection}

New Zealand's department of labour has admitted that a British researcher who contracted meningococcal septicaemia in 2005 probably became infected while working at a government laboratory. Jeannette Adu-Bobie, a meningococcal vaccine researcher, lost both legs, her left arm and the digits of her right hand as a result of the infection. She maintained that she contracted the disease while working at the government's Institute for Environmental Science and Research in Porirua. Previously, the government had said that it was "extremely unlikely" she had contracted the disease there.

But a report released on 3 August by Geraint Emrys, a government adviser, concludes that Adu-Bobie probably did catch the disease at the laboratory. The government has apologized and has offered to pay roughly NZ $\$ 450,000$ (US $\$ 330,000$ ) in damages and medical expenses.

\section{Germany tinkers with university regulations}

It's not the special law for science that researchers were hoping for, but last week the German government announced a series of regulations to make scientists' lives easier.

Most of German science falls under civilservice rules, which has led to a stultifying bureaucracy at odds with modern needs. But while scientists continue to negotiate for a fundamental change to the constitution, research minister Annette Schavan has identified areas where flexibility can be introduced under existing laws.

For example, as of January 2009, state-funded research institutions and universities will be able to supplement fixed salaries to allow them to attract and keep top scientists. And they will be able to build new labs and other research infrastructure without having to go through lengthy procedures for permission to bypass strict building rules designed for office buildings. 